\title{
Predictive models of the preferential distribution of demersal fish larvae in the southern part of the California Current
}

\author{
Maria Teresa Peiro-Alcantar ${ }^{1}$, René Funes-Rodríguez ${ }^{1}$, Reginaldo Durazo ${ }^{2}$, Raúl O. Martínez- \\ Rincón ${ }^{3}$, Rogelio González-Armas ${ }^{1}$, Sergio Hernández Trujillo ${ }^{1}$ \\ ${ }^{1}$ Instituto Politécnico Nacional-Centro Interdisciplinario de Ciencias Marinas, Apdo. Postal 592, La Paz, B.C.S. 23096, \\ Mexico. \\ (MTP-A) E-mail: tere_peiro@ hotmail.com. ORCID iD: https://orcid.org/0000-0003-3550-8456 \\ (RF-R) (Corresponding author) E-mail: rfunes@ipn.mx. ORCID iD: https://orcid.org/0000-0002-6139-0861 \\ (RG-A) E-mail: rarmas@ipn.mx. ORCID iD: https://orcid.org/0000-0003-4027-6143 \\ (SHT) E-mail: strujil@ipn.mx. ORCID iD: https://orcid.org/0000-0002-2533-3915 \\ ${ }^{2}$ Universidad Autónoma de Baja California-Facultad de Ciencias Marinas, Apdo. Postal 453. Ensenada, B.C. 22860, \\ Mexico. \\ (RD) E-mail: rdurazo@uabc.edu.mx.ORCID iD· https://orcid.org/0000-0002-3290-8633 \\ ${ }^{3}$ CONACYT-Centro de Investigaciones Biológicas del Noroeste, La Paz, B.C.S. 23096, México. \\ (ROM-R) E-mail: raul.martinez.rincon@gmail.com. ORCID iD: https://orcid.org/0000-0002-1204-716X
}

\begin{abstract}
Summary: Habitat characterization provides predictive information about the distribution of species and is useful for assessing habitat quality and population stability. Larval abundance of six frequent and abundant demersal species and the relationship of each with the environment were analysed through generalized additive models to determine their preferential distribution and predictive response to the environmental variables in the southern part of the California Current $\left(25-31^{\circ} \mathrm{N}\right)$ between two periods of data collection: 1997-2000 and 2006-2010. Essentially, the main associated variables governing the distribution patterns were related to common and oceanographic characteristics of the water column (temperature and salinity at $50 \mathrm{~m}$ depth, dynamic height and degree of water column stratification); however, the set of variables and their ranges are usually species-specific. Species of northern distribution, Sebastes sp. and Citharichtys stigmaeus, were recorded mainly in newly emerged, relatively unstratified waters characterized by a shallow mixed layer and low temperatures. Low dynamic height values were the most significant predictor of larval distribution for Merluccius productus. Citharichthys xanthostigma and Symphurus atricaudus were widespread, distributed across the study area mainly in autumn in unstratified or stratified waters and at a shallow mixed layer. Particularly C. xanthostigma and S. lucioceps were related to high dynamic height values, likely influenced by a coastal flow towards the pole, as evidenced by counter-currents.
\end{abstract}

Keywords: demersal fish larvae; environmental variables; preferred habitat; California Current.

Modelos predictivos de la distribución preferencial de larvas de peces demersales en la parte sur de la corriente de California

Resumen: La caracterización del hábitat proporciona información predictiva sobre la distribución de las especies y es útil para evaluar la calidad del hábitat y estabilidad de la población. La abundancia larval de seis especies demersales frecuentes y abundantes y de su relación con el medio ambiente se analizaron a través de modelos aditivos generalizados (GAM) para determinar su distribución preferencial y respuesta a las variables ambientales en la parte sur de la corriente de California $\left(25-31^{\circ} \mathrm{N}\right)$ entre dos periodos de datos recolectados 1997-2000 y 2006-2010. Esencialmente, las principales variables asociadas que rigen los patrones de distribución fueron en términos de las variables comunes y oceanográficas de la columna de agua (temperatura y salinidad a $50 \mathrm{~m}$ de profundidad, altura dinámica y grado de estratificación de la columna de agua), sin embargo, el conjunto de variables y los rangos suelen ser específicos de la especie. Especies con distribución norteña, Sebastes sp. y Citharichtys stigmaeus, se registraron principalmente en aguas de surgencia, identificadas por aguas relativamente no estratificadas, poca profundidad de capa mixta y menor temperatura; y menor altura dinámica, como el predictor más significativo de la distribución de larvas de Merluccius productus. Citharichthys xanthostigma y Symphurus atricaudus se distribuyeron ampliamente a lo largo del área de estudio preferentemente en otoño, en aguas no estratificadas o estratificadas y baja profundidad de la capa de mezcla, pero particularmente $C$. xanthostigma y $S$. lucioceps en valores altos de alturas dinámicas probablemente influenciadas por el flujo costero hacia el polo indicado por las contracorrientes.

Palabras clave: larvas de demersales; variables ambientales; hábitat preferencial; corriente de California.

Citation/Como citar este artículo: Peiro-Alcantar M.T., Funes-Rodríguez R., Durazo R., Martínez-Rincón R.O., GonzálezArmas R., Hernández Trujillo S. 2020. Predictive models of the preferential distribution of demersal fish larvae in the southern part of the California Current. Sci. Mar. 84(3): 253-261. https://doi.org/10.3989/scimar.04996.11A 
Editor: J. Salat.

Received: September 13, 2019. Accepted: May 19, 2020. Published: June 17, 2020.

Copyright: (C) 2020 CSIC. This is an open-access article distributed under the terms of the Creative Commons Attribution 4.0 International (CC BY 4.0) License.

\section{INTRODUCTION}

In ocean ecosystems, habitat characterization provides predictive information on the spawning habitat and distribution of species, which is important for understanding the factors that regulate spawning and could be used for assessing ongoing changes in the pelagic ecosystem (Ibaibarriaga et al. 2007, Bernal et al. 2007, Bautista-Romero et al. 2018). The preferred distribution reflects positive habitat selection either by breeders or through higher survival of eggs and larvae (Asch and Checkley, 2013). In this regard, knowledge of the three-dimensional characteristics of the water column (physical process and productive waters) is particularly important for predicting spawning and distribution of some species (Weber and McClatchie 2010, Lynn 2003). Additionally, fish assemblages vary according to midwater oxygen content, sea surface temperature and advection by the California Current, which in many cases covary with basin-scale indices (Koslow et al. 2013). Hence, determining habitat quality is the key aspect for explaining recruitment variability (Ibaibarriaga et al. 2007, Kitchens and Rooker, 2014).

The habitat characterization of fish larvae facilitates the identification of the key set of variables governing the permanence and distribution of organisms. It is known that in demersal fish species, larval abundance responds to seasonal variability of environmental forcing, which is closely related to reproductive periods, geographic location and potential habitat for the expansion or shrinkage of the distribution range (Bailey 1981, Funes-Rodríguez et al. 2009, Peiro-Alcantar et al. 2016). On the western coast of the Baja California Peninsula, larval fluctuations are related to the predominance of sub-Arctic water in winter-spring and part of summer, in addition to the warming effect of surface and subsurface counter-currents from late summer to autumn to the south of the peninsula (Durazo and Baumgartner 2002, Durazo 2015, Valle-Rodríguez and Trasviña-Castro 2017). Additionally, other oceanic processes that promote changes in thermohaline structure and hydrostatic stability occur across spatial scales. These include coastal upwelling, eddies, jets, filaments, fronts, and El Niño Southern Oscillation (ENSO), all of which reflect the transitional nature of water masses (Roden 1991, Lynn and Simpson 1987, Durazo 2015).

The demersal fish larval community in the southern portion of the California Current system is highly diverse and splits into two larval assemblages around Punta Eugenia and Bahía Sebastián Vizcaíno $\left(28^{\circ} \mathrm{N}\right)$ (Peiro-Alcantar et al. 2016). One assemblage congregates to the north, characterized by the predominance of species of sub-Arctic-transitional affinity (winter-spring). The other appears to the south, com- posed mostly of species of subtropical affinity during summer-autumn (Funes-Rodríguez et al. 2009, Peiro-Alcantar et al. 2016), including some species of fishing importance (e.g., Merluccidae, Scorpaenidae, Pleuronectidae)

The objectives of this study are to characterize the habitat of the dominant demersal fish larvae across the distribution range from data collected in the southern part of the California Current (1997-2000 and 2006-2010) and to assess their seasonal response to environmental variables. Knowing how environment and ecological patterns regulate these populations will allow a better understanding to predict the optimal and limiting factors across their geographic distribution range.

\section{MATERIALS AND METHODS}

Biological and hydrographic information was recorded for a total of 1319 samples collected during 22 oceanographic cruises carried out with seasonal periodicity on the western coast of the Baja California Peninsula, Mexico, in 1997-2000 and 2006-2010 (25$31^{\circ} \mathrm{N}$; Fig. 1). Five cruises were conducted in winter (January 1998, 1999, 2000, February 2006, 2008), five in spring (April 1999, 2000, 2006, 2008, 2010), six in summer (July 1998, 2000, 2006, 2008, August 1999, 2007), and six in autumn (September 1997, 1998, October 1999, 2000, 2008, 2009). During El Niño events in 1997 and 1998, large positive temperature and salinity anomalies persisted in the region (Durazo and Baumgartner 2002), while in La Niña, from late 1998 to late 2002, cooler and fresher conditions were observed (Durazo 2009).

The sampling plan included 85 stations in waters off the Baja California Peninsula as part of the Mexican California Current Research Program (IMECOCAL), similar to the arrangement of stations of the California Cooperative Oceanic Fisheries Investigations (CalCOFI) program in Mexican waters. The distance between stations was $\sim 35 \mathrm{~km}$ along transects that were set perpendicular to the coastline, separated $\sim 70 \mathrm{~km}$ from each other (Fig. 1). At each station, vertical casts were conducted using a factory-calibrated CTD (Sea-Bird) fitted with dual conductivity and temperature sensors. The explanatory variables included sea surface temperature and salinity at $50 \mathrm{~m}$ depth, absolute dynamic height (ADT; dyn cm; http://marine.copernicus.eu), mixed layer depth, water column stratification $\left(\varphi, \mathrm{J} \mathrm{m}^{3}\right.$; Simpson et al. 1990) at a 0-50 m range across the water column, and spatial and temporal information [geographic coordinates (latitude-longitude) and season]. We used ADT data because these allow a wider view of the surface ocean circulation during each cruise than the spatial scope of in situ dynamic height calculations; however, the two were similar. 


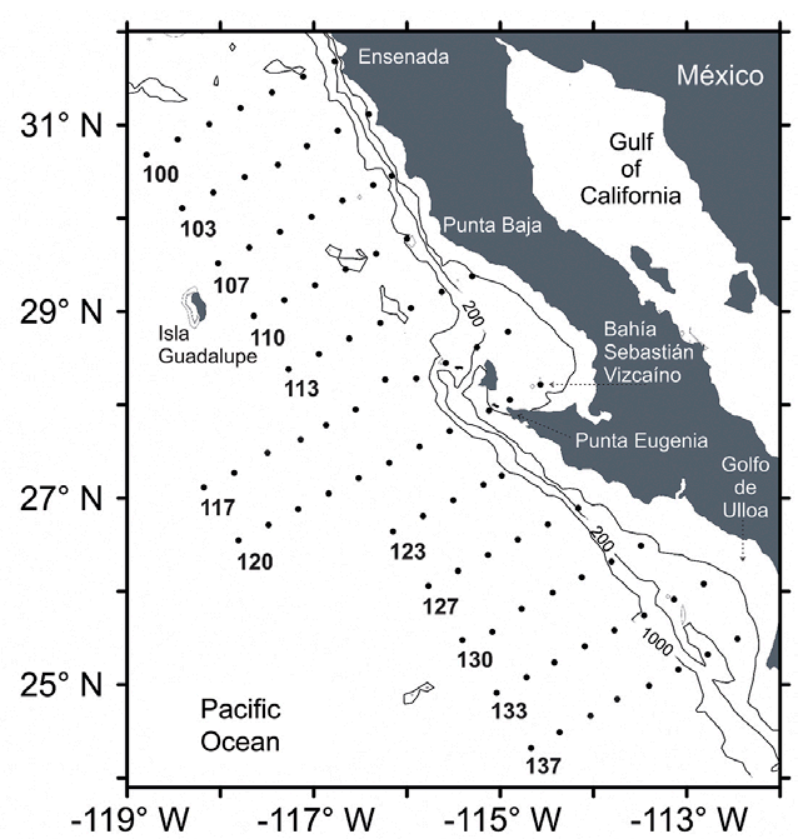

Fig. 1. - Basic station plan of the IMECOCAL programme on the western coast of the Baja California Peninsula. Contours indicate the bathymetry at 100 and $200 \mathrm{~m}$ depth.

Plankton samples were collected with Bongo nets (0.61 m mouth diameter; $505 \mu \mathrm{m}$ mesh size) fitted with digital flowmeters to measure filtered water volume. Nets were towed obliquely to the surface from a maximum depth of $\sim 200 \mathrm{~m}$. Samples were preserved in $4 \%$ borate-buffered formaldehyde in seawater. Ichthyoplankton was sorted from plankton samples and larvae were identified to species level (Moser 1996). Fish larval abundances were standardized to larvae per $10 \mathrm{~m}^{2}$ of marine sea surface for comparison with other studies in the California Current; detailed descriptions of gear, sampling procedures, and standardization are given in Smith and Richardson (1977). The most frequent and abundant demersal taxa were selected to characterize their habitat (Peiro-Alcantar et al. 2016), including species subjected to large-scale commercial exploitation and recreational fishing (Merluccius productus, Sebastes sp.), and others of lesser commercial interest (Citharichthys stigmaeus, C. xanthostigma, Symphurus atricaudus and Synodus lucioceps). Sebastes is a speciose genus characteristic of sub-Arctic to warm temperate zones. The Sebastes sp. larvae used here belong to the most frequent and abundant morphotype; their larvae were somewhat more abundant off central California and declined south of the Southern California Bight (Smith and Moser 2003).
Generalized additive models (GAMs) were used to investigate the influence of spatial, temporal and environmental factors on demersal fish larvae on the western coast of the Baja California Peninsula. The use of GAMs in fish habitat modelling is valuable for exploring species-environment relationships, seeking to predict the habitat preference of adults in the reproduction stage and the potential habitat of larvae (Weber and McClatchie 2010, Kitchens and Rooker 2014). All GAMs were performed in R (R Core Team 2017) using the mgcv package (Wood 2011). Since response variables are abundance data (continuous and positive values), the fitted GAMs used the Gaussian distribution family with $\log$ as a link function. The log link function was used to reduce the high overdispersion of data. The level of smoothing (i.e. the number of bases (k) in smoothing functions) for each predictor variable was restricted to 4 to avoid overfitting. Collinearity among variables was examined using the Pearson correlation coefficient, so highly correlated variables $(\mathrm{R}>0.7)$ were removed from the models. Since temperature at $50 \mathrm{~m}$ depth and dynamic height were highly correlated $(\mathrm{R}>0.7)$, only one of these two variables was used in the models, depending on its contribution to the model. Thus, we used up to seven predictor variables with a low correlation (Table 1) in the final models. This technique has been used successfully to describe species-environment relationships and to predict habitat preferences or potential habitat distribution (Austin 2007, Elith and Leathwick 2009). The mathematical representation of the GAM applied to abundance of selected species can be expressed as follows:

$$
\begin{gathered}
\log (\text { abundance })=\alpha+f_{1} X_{1}+f_{2} X_{2}+f_{3} X_{3}+f_{4} X_{4}+ \\
+f_{5} X_{5}+f_{6} X_{6}+X_{7}
\end{gathered}
$$

where $\alpha$ and $X_{n}$ denote intercept, longitude and latitude (interaction term), temperature, dynamic height, salinity, mixed layer depth, water column stratification and season (as a parametric term), respectively; and $\mathrm{f}_{\mathrm{n}}$ are smoothing functions (thin plate regression spline) (Wood 2011).

\section{RESULTS}

\section{Surface ocean circulation}

Seasonal climatology maps of the ADT (19932013) show the cyclonic eddy of Southern California clearly visible in winter, summer and autumn (Fig. 2A, $\mathrm{C}, \mathrm{D})$. There is also an increase in the number of mes-

Table 1. - Correlation matrix for spatial (longitude and latitude) and environmental factors [temperature and salinity (50 m depth); dynamic height; mixed layer depth (MLD); and water column stratification (Phi)]. Lower diagonal are Pearson's correlation coefficients, upper diago-

\begin{tabular}{|c|c|c|c|c|c|c|c|}
\hline & Latitude & Longitude & D. height & Temperature & Salinity & MLD & Phi \\
\hline Latitude & - & 0.000 & 0.000 & 0.000 & 0.000 & 0.165 & 0.000 \\
\hline Longitude & -0.713 & - & 0.000 & 0.346 & 0.000 & 0.000 & 0.000 \\
\hline D. height & -0.141 & -0.154 & - & 0.000 & 0.000 & 0.000 & 0.000 \\
\hline Temperature. & -0.336 & -0.026 & 0.749 & & 0.000 & 0.000 & 0.000 \\
\hline Salinity & -0.446 & 0.476 & 0.137 & 0.307 & - & 0.000 & 0.095 \\
\hline MLD & 0.039 & -0.182 & 0.280 & 0.396 & 0.198 & - & 0.000 \\
\hline Phi & -0.142 & 0.309 & -0.259 & -0.434 & 0.046 & -0.562 & - \\
\hline
\end{tabular}
nal are $\mathrm{p}$ values. 


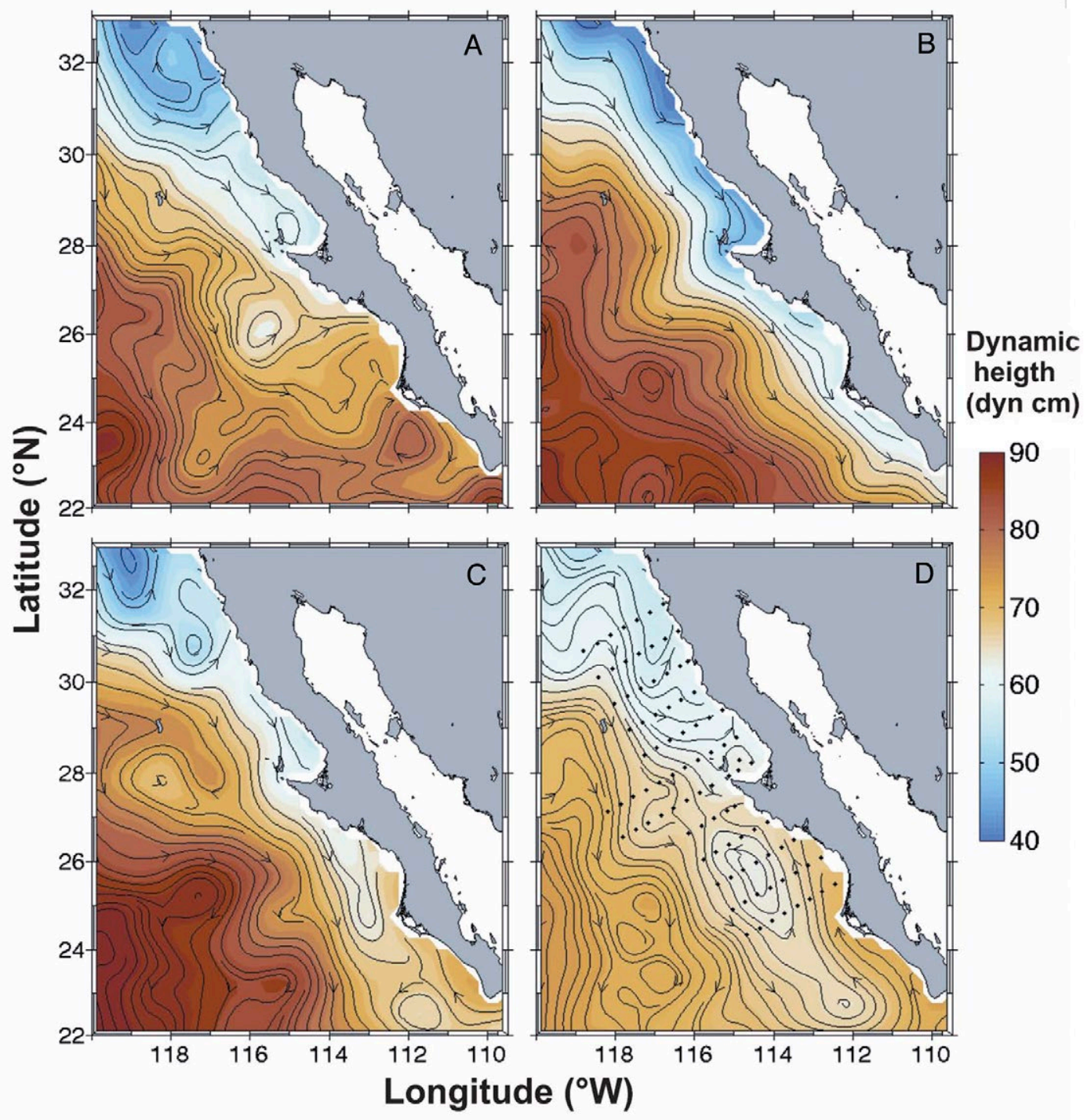

Fig. 2. - Seasonal climatology of absolute dynamic height of sea surface (ADT) during the period 1993-2013. A, winter; B, spring; C, summer; and $\mathrm{D}$, autumn. Colours indicate the elevation of the ocean surface $(\mathrm{cm})$ and line contours mark the trajectory of surface currents associated with elevation.

oscale structures related to an anticyclonic flow, with an elongated meander being more pronounced during summer and autumn (Fig. 2D). Sea surface circulation is mostly towards the equator during spring and summer. This flow, which corresponds to the California Current, is driven by the prevailing southward winds. In spring, when winds along the coast are stronger, upwelled waters near the coast have lower temperature and consequently display the lowest elevation along the entire peninsula (Fig. 2B). Upwelled water is evident in the sea level minimums (ADT) and is reduced significantly in summer and autumn, especially in the region south of $28^{\circ} \mathrm{N}$ (Fig. 2C, D). Also during spring, mesoscale structures are reduced and the cyclonic gyre of Southern California is non-existent.

In the southern region, a coastal flow towards the pole is evident in summer and increases in autumn (Fig. 2C, D), as indicated by counter-currents. During summer-autumn, connectivity may be established between waters of tropical origin from the southern
Table 2. - Performance of the best-fitted GAMs for six demersal species. Adj. $\mathrm{R}^{2}$, adjusted $\mathrm{R}^{2}$; Dev. exp., deviance explained.

\begin{tabular}{llc}
\hline \multicolumn{1}{c}{ Species } & Adj. $\mathrm{R}^{2}$ & Dev. exp. (\%) \\
\hline Merluccius productus & 0.690 & 69.2 \\
Sebastes sp. & 0.727 & 72.6 \\
Citharichtys stigmaeus & 0.735 & 72.8 \\
Citharichtys xanthostigma & 0.527 & 51.2 \\
Symphurus atricaudus & 0.653 & 65.7 \\
Synodus lucioceps & 0.996 & 99.6 \\
\hline
\end{tabular}

margin of the peninsula and the Pacific anticyclonic gyre (subtropical waters) from the eastern margin, as indicated by current lines (Fig. 2C, D).

\section{Habitat characterization}

Performances of the best-fitted models are shown in Table 2. Effect plots of the best-fitted models (Fig. 3 ) were used to describe the effect of environmental, temporal and spatial factors on selected demersal 

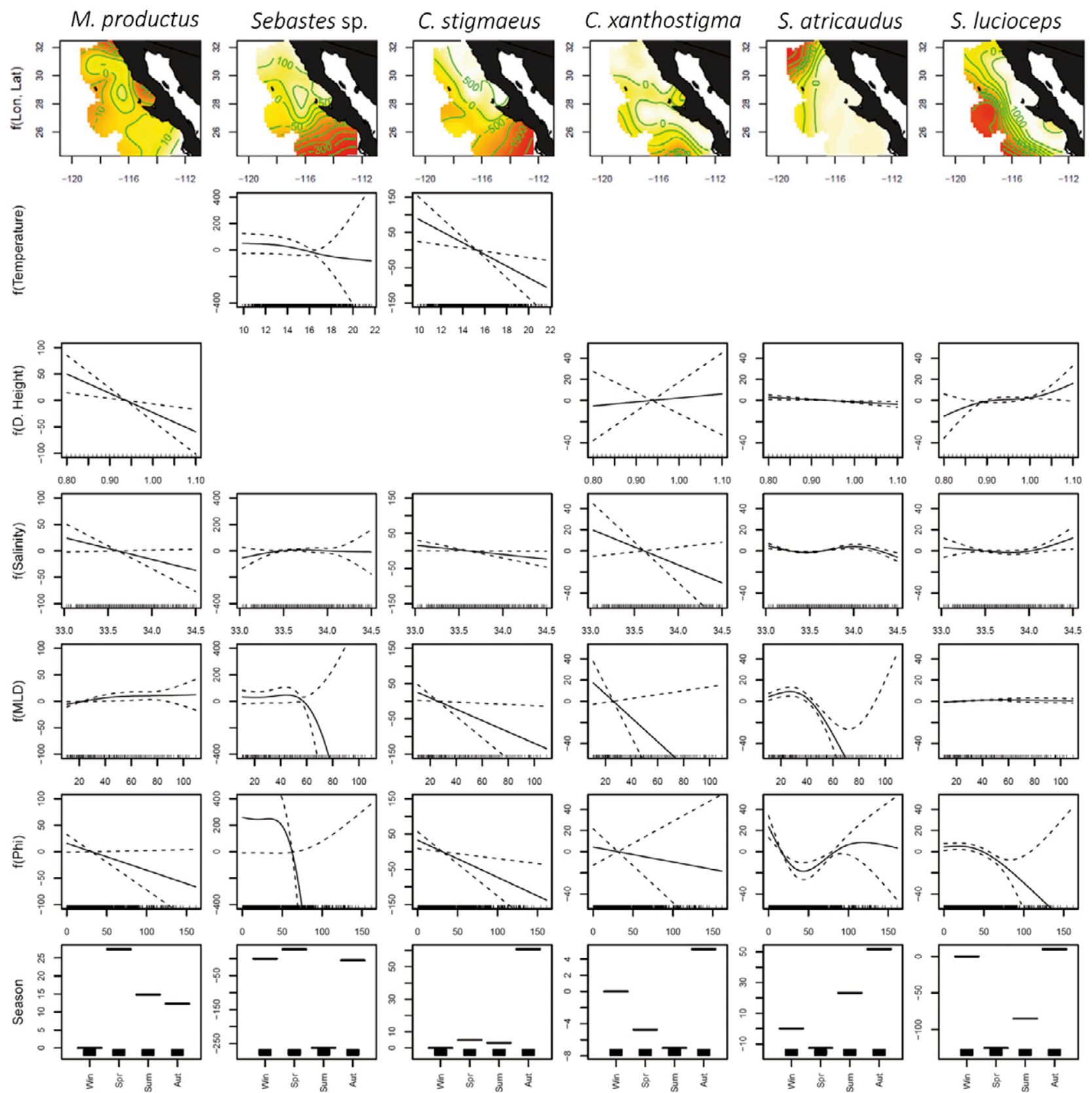

Fig. 3. - Response plots for predictor variables of larvae of six demersal species off the western coast of the Baja California Peninsula during the study period (1997-2000 and 2006-2010) from the best-fitted GAMs. Contour plots indicate species preferred distributions with values on the response scale given by the contours, with lighter colour indicating higher values. The solid line indicates the smooth function or the parametric coefficients; the dashed lines are the standard error and tick marks at the foot of each plot are observations of the covariates.

fish larvae on the west coast of the Baja California Peninsula.

\section{Preference in winter-spring}

M. productus is expected to occur principally in spring in coastal and offshore waters in the northern area $\left(29-31^{\circ} \mathrm{N}\right)$, associated with lower dynamic height $(<0.9 \mathrm{~m})$ and lower salinity $(<33.5$ at $50 \mathrm{~m}$ depth $)$, in relatively unstratified waters $(\mathrm{Phi}<50 \mathrm{~m})$ over a wide range of mixed layer depths $(40-100 \mathrm{~m})$. The higher abundance of Sebastes sp. is predicted to occur during the spring in coastal and offshore waters in the northern area, but the model suggests that Bahía de Sebastian Vizcaíno $\left(29^{\circ} \mathrm{N}\right)$ is also important. This species is estimated to occur at lower temperatures $\left(<16^{\circ} \mathrm{C}\right.$ at 50 $\mathrm{m}$ depth) and salinity (33.4-34.0 at $50 \mathrm{~m}$ depth) at a shallow mixed layer depth $(<60 \mathrm{~m})$. A higher abundance of $C$. stigmaeus occurs mainly in the northern area $\left(29-31^{\circ} \mathrm{N}\right)$, associated with lower temperature and salinity $\left(<16^{\circ} \mathrm{C}\right.$ and $<33.5$, respectively), in areas with a shallow mixed layer $(<20 \mathrm{~m})$ and unstratified water (Phi<30 m).

In general, $M$. productus and Sebastes sp. showed a preference for coastal and oceanic waters of the northernmost region in spring. These species of northern 
distribution, including C. stigmaeus, were recorded in waters where temperature and salinity are lower, in relatively unstratified waters and at a shallow mixed layer. The exception is $M$. productus, which was found over a wide range of mixed layer depths, and is expected to occur when the dynamic height is lower. This suggests a preference of these species for northern coastal areas, where the winds along the coast are stronger and unstratified waters are consequently related to newly emerged waters along the peninsula, during the main flow of the California Current sea surface circulation towards the equator.

\section{Preference in summer-autumn}

A higher abundance of $C$. xanthostigma is expected to occur in the northern zone, with a core of peak abundance just off Punta Baja $\left(30^{\circ} \mathrm{N}\right)$. Although dynamic height has little effect on this species, it is predicted to occur when dynamic height is higher $(>0.95 \mathrm{~m})$, associated with lower salinity $(<33.5)$ and unstratified waters $(\mathrm{Phi}<30 \mathrm{~m})$ in areas with shallow mixed layers $(<20 \mathrm{~m})$. In the case of $S$. atricaudus, the highest abundance occurs in coastal waters across the study area during the autumn. The model suggests a preference for lower dynamic height $(<0.80 \mathrm{~m})$ in areas with shallow mixed layer $(<40 \mathrm{~m})$, with low-to-high water column stratification ( $<20 \mathrm{~m}$ and $>100 \mathrm{~m}$ depth) and salinities (33.0 and 34.0). Higher abundances of $S$. lucioceps should occur during the autumn in coastal waters centred on the wide continental shelf, mainly in Bahía Sebastián Vizcaíno $\left(28^{\circ} \mathrm{N}\right)$ and to the south. This species is associated with higher dynamic height $(<1.0 \mathrm{~m})$ and salinity $(>34.0)$ in unstratified waters (Phi<30 m).

These species of widespread distribution across the study area are centred on the wide continental shelf in Bahía Sebastián Vizcaíno $\left(28^{\circ} \mathrm{N}\right)$ and to the south, except for $C$. xanthostigma, which occurs mainly in the northern zone. Although $C$. xanthostigma is estimated to occur at relatively lower salinities (contrasting with $S$. atricaudus and S. lucioceps, which are reported over a relatively broader range), none of the species was related to temperature. Except for $S$. atricaudus, these species are expected to occur associated with peak sea levels in relation to the countercurrent flow south of $28^{\circ} \mathrm{N}$ during summer and autumn.

\section{DISCUSSION}

The preferred habitat distribution of fish larvae was analysed with the use of GAMs in order to identify the most significant environmental and geographic predictors in the southern waters of the California Current. The analysis allowed a set of variables to be identified according to habitat requirements that are usually specific, rather than the influence of a single variable. In this regard, it has been pointed out that combinations of ocean variables may directly or indirectly serve as predictors of spawning areas (Weber and McClatchie 2010, Asch and Checkley 2013, Checkley et al. 2017).

\section{Preference in winter-spring}

M. productus, Sebastes sp., and C. xanthostigma belong to the so-called "Northern Complex", distributed in the north-south plane across the area of influence of the California Current, but probably close to the coast when their distribution reaches the southern waters off the peninsula (Moser et al. 1987). C. stigmaeus and $C$. xanthostigma display a particular affinity for warm water, but are included in the "Northern Complex" due to the high affinity with the northern anchovy, Engraulis mordax; C. stigmaeus is the most temperate taxon in this group (Moser et al. 1987). The distribution of the slope/transitional larval fish assemblage is primarily related to the bathymetric range of adults.

Larvae of $M$. productus and Sebastes sp. show the Southern California Bight as their preferential distribution centre, while larvae of Sebastes sp. and Citharichtys stigmaeus are distributed across the California Current (Moser et al. 1993, Bautista-Romero et al. 2018). In contrast, C. xanthostigma, Synodus lucioceps, and Symphurus atricaudus are associated with fauna in warm to temperate areas (Moser et al. 1987). Their distribution is limited to the Baja California peninsula, mainly in the vicinity of Punta Eugenia $\left(28^{\circ} \mathrm{N}\right)$, although Symphurus spp. and C. xanthostigma also occur with a low frequency in southern California (Moser et al. 1993).

The highest larval abundances of $M$. productus (Bailey et al. 1981, Funes-Rodríguez et al. 2009) and Sebastes spp. (Moser and Boehlert 1991, Moser et al. 1993) are consistent with those reported for coastal and slope waters north of the peninsula, closely related to the habitat used by adults and larvae. A second increase in $M$. productus to the south of the peninsula was also observed, evidenced as latitudinal differences in abundance, which seemed to break at Punta Eugenia $\left(28^{\circ} \mathrm{N}\right)$. This distribution is probably related to the stock of dwarf hake, similar to the findings reported by FunesRodríguez et al. (2009). Additionally, the abundance of $M$. productus decreases off Punta Baja $\left(\sim 30^{\circ} \mathrm{N}\right)$, apparently bordered by waters transported towards the coast from the outer margin of the California Current around Isla Guadalupe. This finding could be related to an anticyclonic flow around an elongated meander, such as the one described by Durazo and Baumgartner (2002) and Soto-Mardones et al. (2004). These observations also explain the transport of mesopelagic larvae to the coast (Funes-Rodríguez et al. 2011) and the partition of the breeding area of coastal species (Aceves-Medina et al. 2018).

M. productus and Sebastes sp. occur mainly in winter-spring and are scarce in other seasons of the year (Moser and Boehlert 1991, Moser et al. 1993, Funes-Rodríguez et al. 2009). In this study, their larvae occurred principally in spring under sub-Arctic waters characteristic of the California Current. The current is defined by more homogeneous flow off Baja California, intense winds that favour coastal upwelling, low temperature and salinity from the surface to 100 $\mathrm{m}$ depth off California, and maximum coast-to-ocean slope at the sea surface, mainly in spring (Lynn and 
Simpson 1987, Soto-Mardones et al. 2004, Durazo 2009, 2015).

The most significant environmental predictors of both species were similar and defined mostly by the seasonal variation in the strength of the California Current southward flow along the west coast of the Baja California Peninsula. Although larvae of M. productus are positively related to relatively lower SST, other studies (Bjorkstedt et al. 2002, Bautista-Romero et al. 2018) recorded a preference for low salinity, low dynamic height and unstratified water in a wide mixed layer depth. This preference explains the broad distribution of $M$. productus larvae in waters south of the peninsula. Similarly, larvae of Sebastes sp. are related to unstratified waters and low temperatures, these parameters being the most significant predictors of its larval distribution, as evidenced in localities with low SST, high geostrophic flow or lower ADT values in other studies (Weber and McClatchie 2010, Ash and Checkley 2013, Kosllow et al. 2013). This would explain the relationship with other species that take advantage of inshore areas in spring, characterized by highly productive and relatively stable conditions in the Southern California Bight (Weber and McClatchie 2010).

Upwelling areas may exert major effects in the planktonic stages, derived from the advection of eggs and larvae outside of breeding areas and consequently affecting the recruitment of stocks (Bailey 1981, Sakuma and Ralston 1997). Similarly, the scarcity of larvae of coastal species is associated with the region of upwelling and offshore Ekman transport, suggesting that adults avoid spawning in upwelling areas, thus avoiding offshore transport of their larvae into the California Current (Doyle et al. 1993). Although coastal species with benthic eggs tend to be relatively scarce during the upwelling season in Angola Bay, three species of flatfishes showed positive responses to upwelling events. These were associated with the highest microzooplankton biomass, suggesting that the spawning of these species is timed to maximize food availability (Pattrick and Strydom 2014).

To compensate for the effect of the offshore Ekman transport, the spawning season in $\mathrm{M}$. productus and $\mathrm{Se}$ bastes sp. occurs in early winter in California (Moser et al. 1993), when offshore transport shows a seasonal decrease $\left(36-27^{\circ} \mathrm{N}\right.$, Bailey 1981). Additionally, most late eggs and larvae of $M$. productus are located near or within the thermocline (Ahlstrom 1959, Cass-Calay 1997, Moser et al. 1997) limited by the mixing layer, in a vertical distribution range below the photic layer (50-100m depth) (Sakuma et al. 2007). Larvae of Sebastes sp. are captured mainly within the mixed layer (Sakuma et al. 2007) and increase abruptly in abundance near upwelling fronts (Moser and Boehlert 1991, Bjorkstedt et al. 2002). This finding is likely associated with surface convergence related to the increased thermocline slope, so the distribution of fish larvae may change along the pycnocline slope associated with fronts (Bjorkstedt et al. 2002). In other regions, larvae of flatfishes showed positive responses to upwelling events, suggesting that spawning is timed to maximize food availability for larvae in Algoa Bay. However, larvae hatching from benthic eggs tend to be larger and more developed upon hatching than those from pelagic eggs, and would therefore have some enhanced ability to resist transport (Pattrick and Strydom 2014).

\section{Preference in summer-autumn}

Larvae of $C$. xanthostigma and $C$. stigmaeus occur mainly in the second half of the year, the latter throughout winter (Moser et al. 1993, Bautista-Romero et al. 2018). During the second half of the year, a reduced core of sub-Arctic water occurs as far south as the tip of the peninsula $\left(28^{\circ} \mathrm{N}\right)$. This leads to a progressive narrowing of the California Current near the surface as a result of mixing with warmer and more saline waters along its southerly path (Durazo 2015), governed by a warm countercurrent on the southern margin of the peninsula (Valle-Rodríguez and Trasviña-Castro 2017). Both species exhibited the best fit to the model at low salinities and a mixed layer depth. Dynamic height had little or no effect on these species, which occur mainly associated with the eastern margin of the Pacific gyre in a poorly stratified water column. Similarly, other studies have reported higher catches of Coryphaena hippurus larvae near fronts and eddies in the northern Gulf of Mexico (Kitchens and Rooker 2014).

Citharichthys spp. larvae may migrate vertically through the thermocline and pycnocline, which could favour recruitment to settlement areas near the coast (Sakuma and Ralston 1997, Sakuma et al. 1999). In this study, flatfish larvae preferred coastal shelf waters, with some species (e.g. S. atricaudus and S. lucioceps) preferentially distributed across a wide continental shelf in Bahía Sebastián Vizcaíno. This finding is consistent with other regions where the narrow continental shelf reduces the potential spawning habitat (e.g. sardine), with clear limits in terms of temperature and bottom depth in European Atlantic waters (Bernal et al. 2007). Additional examples are the high larval density and number of coastal and shelf species on the coastal side, apparently limited by the shelf-slope front off the northern Catalan coast (Sabatés and Olivar 1996). However, in other areas the largest number of early stages occur in shelf waters of high productivity influenced by large rivers, such as the Bay of Biscay (Ibaibarriaga et al. 2007) and the Columbia River plume (Doyle et al. 1993). This is not the case of the subtropical Baja California Peninsula, a region with negligible freshwater input, favourable winds and upwelling events over the whole year, which peak from spring to early summer (Durazo 2015).

$S$. atricaudus and S. lucioceps are part of the socalled "Southern Coastal Complex", distributed mainly in the coastal zone around Punta Eugenia $\left(28^{\circ} \mathrm{N}\right)$ (Moser et al. 1987). Despite their similar geographic distribution, the preferred habitat of each of these two species differs. S. lucioceps thrives mainly in relatively homogeneous waters with high dynamic height and salinity, even when their larvae occur throughout the year with peak abundance in autumn (Moser et al. 1993). 
For its part, S. atricaudus occurs in areas with shallow mixed layer depth and unstratified waters. This is consistent with its peak seasonal abundance (summerautumn), as it remains within cyclonic eddies around Punta Eugenia and thus avoiding offshore transport, while settlement occurs in late autumn and winter (Charter and Moser 1996).

In summary, oceanic circulation and environmental forcing have significant consequences (extension and delimitation) in the distribution of demersal fish larvae in the southern part of the California Current. Using GAMs to explore the preferred habitat allowed us to identify common environmental variables that influence larval distribution (temperature, salinity, dynamic height and degree of column stratification). This is possible since larval associations reveal that different species share similar life cycles despite the dispersive environment. The fact that these occur sympatrically (eggs and larvae) may contribute to their being affected by the same mechanisms (Moser and Smith 1993). However, the set of variables and ranges where habitat preference is maximized is usually species-specific, and this allows a better description of the most important environmental characteristics that are closely related to the habitat used by adults and larvae.

\section{ACKNOWLEDGEMENTS}

This work was supported by the IMECOCAL programme (Consejo Nacional de Ciencia y Tecnología, CONACyT grants G0041T, 017P ̃̃-1297 and G35326T) and the Instituto Politécnico Nacional (IPN) (Secretaria de Investigación y Posgrado, SIP grants 20190126 and 20200645). We thank the staff of the Plankton Laboratory at the Centro de Investigación Científica y Educación Superior de Ensenada for sample collecting and processing. We thank S.P.A. Jiménez-Rosenberg (period 1997-2000) and E. AnayaGodínez (period 2006-2010) for their assistance in the identification of fish larvae. MTPA received financial support from CONACyT and a Beca de Estímulo Institucional de Formación de Investigadores (BEIFI). RFR, RGA, and SHT are grant recipients of the Comisión de Operación y Fomento de Actividades Académicas (COFAA) and Estímulos al Desempeño de los Investigadores (EDI)-IPN. This study was conducted using EU Copernicus Marine Service Information. María Elena Sánchez-Salazar edited the English manuscript.

\section{REFERENCES}

Aceves-Medina G., Jiménez-Rosenberg S.P.A., Saldierna-Martínez R.J., et al. 2018. Distribution and abundance of the ichthyoplankton assemblages and its relationships with the geostrophic flow along the southern region of the California Current. Lat. Amer. J. Aquat. Res. 46: 104-119. https://doi.org/10.3856/vol46-issue1-fulltext-12

Ahlstrom E.H. 1959. Vertical distribution of pelagic fish eggs and larvae off California and Baja California. Biol. Rep. U. S. Fish Wildl. Serv. 60: 107-146.

Asch R.G., Checkley Jr. D.M. 2013. Dynamic height: A key variable for identifying the spawning habitat of small pelagic fishes. Deep Sea Res. Oceanogr. Part I 71: 79-91. https://doi.org/10.1016/j.dsr.2012.08.006
Austin M. 2007. Species distribution models and ecological theory: a critical assessment and some possible new approaches. Ecol. Model. 200: 1-19.

https://doi.org/10.1016/j.ecolmodel.2006.07.005

Bailey K.M. 1981. Larval transport and recruitment of Pacific hake Merluccius productus. Mar. Ecol. Prog. Ser. 6: 1-9. https://doi.org/10.3354/meps006001

Bautista-Romero J.J., Funes-Rodríguez R., Jiménez-Rosenberg S.P. et al. 2018. Preferential distribution of fish larvae in the California Current System: Time, space, and temperature. Fish. Oceanogr. 27: 259-273. https://doi.org/10.1111/fog.12250

Bernal M., Stratoudakis Y., Coombs S. et al. 2007. Sardine spawning off the European Atlantic coast: Characterization of and spatio-temporal variability in spawning habitat. Prog. Oceanogr. 74: 210-227

https://doi.org/10.1016/j.pocean.2007.04.018

Bjorkstedt E.P., Rosenfeld L.K., Grantham B.A. et al. 2002. Distributions of larval rockfishes Sebastes spp. across nearshore fronts in a coastal upwelling region. Mar. Ecol. Prog. Ser. 242: 215-228. https://doi.org/10.3354/meps242215

Cass-Calay S.L. 1997. Relation of mean growth rate to concentration of prey-sized particles for larvae of Pacific hake (Merluccius productus). Calif. Coop. Ocean. Fish. Invest. Rep. 38: 69-76.

Charter S.R., Moser H.G. 1996. Cynoglossidae: Tonguefishes. In: Moser E.H. (ed.). Early stages of fishes in California Current region, Atlas 33. Calif. Coop. Ocean. Fish. Invest., La Jolla CA, pp 79-81.

Checkley D.M.Jr., Asch R.A., Rykaczewski R.R. 2017. Climate, anchovy, and sardine. Annu. Rev. Mar. Sci. 9: 469-493. https://doi.org/10.1146/annurev-marine-122414-033819

Doyle M.J., Morse W.W., Kendall A.W. 1993. A comparison of larval fish assemblages in the temperate zone of the northeast Pacific and northwest Atlantic oceans. Bull. Mar. Sci. 53: 588-644.

Durazo R. 2009. Climate and upper ocean variability off Baja California, México: 1997-2008. Prog. Oceanogr. 83: 361-368. https://doi.org/10.1016/j.pocean.2009.07.043

Durazo R. 2015. Seasonality of the transitional region of the California Current System off Baja California. J. Geophys. Res., Oceans 120: 1173-1196. https://doi.org/10.1002/2014JC010405

Durazo R., Baumgartner T. 2002. Evolution of oceanographic conditions off Baja California: 1997-1999. Prog. Oceanogr. 54: 7-31. https://doi.org/10.1016/S0079-6611(02)00041-1

Elith J., Leathwick J.R. 2009. Species distribution models: ecological explanation and prediction across space and time. Annu. Rev. Ecol. Syst. 40: 677-697. https://doi.org/10.1146/annurev.ecolsys.110308.120159

Funes-Rodríguez R., Elorduy-Garay J.F., Hinojosa-Medina A.T. et al. 2009. Interannual distribution of Pacific hake (Merluccius productus) larvae in the southern part of the California Current. J. Fish Biol. 75: 630-646. https://doi.org/10.1111/j.1095-8649.2009.02327

Funes-Rodríguez R., Zárate-Villafranco A., Hinojosa-Medina A. et al. 2011. Mesopelagic fish larval assemblages during El Niño Southern Oscillation (1997-2001) in the southern part of the California Current. Fish. Oceanogr. 20: 329-346. https://doi.org/10.1111/j.1365-2419.2011.00587.x

Ibaibarriaga L., Irigoien X., Santos M. et al. 2007. Egg and larval distributions of seven fish species in north-east Atlantic waters. Fish. Oceanogr. 16: 284-293. https://doi.org/10.1111/j.1365-2419.2007.00430.x

Kitchens L.L., Rooker J.R. 2014. Habitat associations of dolphinfish larvae in the Gulf of Mexico. Fish. Oceanogr. 23: 460-471. https://doi.org/10.1111/fog.12081

Koslow J.A., Goericke R., Watson W. 2013. Fish assemblages in the Southern California Current: relationships with climate, 1951-2008. Fish. Oceanogr. 22: 207-219 https://doi.org/10.1111/fog.12018

Lynn RJ. 2003. Variability in the spawning habitat of Pacific sardine (Sardinops sagax) off southern and central California. Fish. Oceanogr. 12: 541-553. https://doi.org/10.1046/j.1365-2419.2003.00232.x

Lynn R.J., Simpson J.J. 1987. The California Current system: the seasonal variability of its physical characteristics. J. Geophys. Res. 92: 12947-12966. 
https://doi.org/10.1029/JC092iC12p12947

Moser H.G. 1996. The Early Stages of Fishes in the California Current Region. Calif. Coop. Ocean. Fish. Invest. Atlas 33, Marine Life Research Program, Scripps Institution of Oceanography, La Jolla CA, 1505 pp.

Moser H.G., Boehlert G.W. 1991. Ecology of pelagic fish larvae and juveniles of the genus Sebastes. Environ. Biol. Fish. 30: 203-224. https://doi.org/10.1007/BF02296890

Moser H.G., Smith P.E. 1993. Larval fish assemblages and oceanic boundaries. Bull. Mar. Sci. 53: 283-289.

Moser H.G., Smith P.E., Eber L.E. 1987. Larval fish assemblages in the California Current region, 1954-1960, a period of dynamic environmental change. Calif. Coop. Ocean. Fish. Invest. Rep. 28: $97-127$

Moser H.G., Charter R.L., Smith P.E. et al. 1993. Distributional Atlas of Fish Larvae and Eggs in the California Current Region: Taxa with 1000 or More Total Larvae, 1951-1984. Calif. Coop. Ocean. Fish. Invest. Atlas 31, Marine Life Research Program, Scripps Institution of Oceanography, La Jolla CA, 233 pp.

Moser H.G, Lo N.C.H., Smith P.E. 1997. Vertical distribution of Pacific hake eggs in relation to stage of development and temperature. Calif. Coop. Ocean. Fish. Invest. Rep. 38: 120-126.

Pattrick P., Strydom N.A. 2014. Larval fish variability in response to oceanographic features in a nearshore nursery area. J. Fish Biol. 85: 857-881. https://doi.org/10.1111/jfb.12477

Peiro-Alcantar M.T., Funes-Rodríguez R., González-Armas R. et al. 2016. Spatiotemporal variability of demersal fish larvae assemblages in the southern region of the California Current. Mar. Biol. Res. 12: 524-540. https://doi.org/10.1080/17451000.2016.1164319

R Core Team. 2017. R: A language and environment for statistical computing. R Foundation for Statistical Computing. Vienna, Austria. https://www.R-project.org/

Roden G.I. 1991. Subarctic-Subtropical Transition Zone of the North Pacific: Large-Scale Aspects and Mesoscale Structure. In: Wetherall J.A. (ed). Biology, Oceanography, and Fisheries of the North Pacific Transition Zone and Subarctic Frontal Zone. NOAA-NMFS Tech. Rep. 105: 1-38.

Sabatés A., Olivar M.P. 1996. Variation of larval fish distributions associated with variability in the location of a shelf-slope front. Mar. Ecol. Prog. Ser. 135: 11-20. https://doi.org/10.3354/meps 135011

Sakuma K.M., Ralston S. 1997. Vertical and horizontal distribution of juvenile Pacific hake (Merluccius productus) in relation to hydrography off California. Calif. Coop. Ocean. Fish. Invest. Rep. 38: 137-146.

Sakuma K.M., Ralston S., Roberts D.A. 1999. Diel vertical distribution of postflexion larval Citharichthys spp. and Sebastes spp. off central California. Fish. Oceanogr. 8: 68-76. https://doi.org/10.1046/j.1365-2419.1999.00088.x

Sakuma K.M., Ralston S., Roberts D.A. 2007. High-frequency patterns in abundance of larval Pacific hake, Merluccius productus, and rockfish, Sebastes spp., at a single fixed station off central California. Fish. Oceanogr. 16: 383-394. https://doi.org/10.1111/j.1365-2419.2007.00440.x

Simpson J.H., Brown D., Matthews G. 1990. Tidal straining, density currents, and stirring in the control of estuarine stratification. Estuaries 2: 125-132 https://doi.org/10.2307/1351581

Smith P.E., Moser H.G. 2003. Long-term trends and variability in the larvae of Pacific sardine and associated fish species of the California Current region. Deep-Sea Res. 50: 2519-2536. https://doi.org/10.1016/S0967-0645(03)00133-4

Smith P.E., Richardson S.L. 1977. Standard techniques for pelagic fish and larvae surveys. FAO Tech. Pap. 175, 99 pp

Soto-Mardones L., Parés-Sierra A., Garcia J. et al. 2004. Analysis of the mesoscale structure in the IMECOCAL region (off Baja California) from hydrographic, ADCP and altimetry data. Deep-Sea Res. 51: 785-798. https://doi.org/10.1016/j.dsr2.2004.05.024

Valle-Rodríguez J., Trasviña-Castro A. 2017. Poleward currents from coastal altimetry: The west coast of Southern Baja California, Mexico. Adv. Space Res. 59: 2313-2324. https://doi.org/10.1016/j.asr.2017.01.050

Weber E.D., McClatchie S. 2010. Predictive models of northern anchovy Engraulis mordax and Pacific sardine Sardinops sagax spawning habitat in the California Current. Mar. Ecol. Prog. Ser. 406: 251-263. https://doi.org/10.3354/meps08544

Wood S.N. 2011. Fast stable restricted maximum likelihood and marginal likelihood estimation of semiparametric generalized linear models. J. R. Stat. Soc. 73: 3-36. https://doi.org/10.1111/j.1467-9868.2010.00749.x 